DOI: https://doi.org/10.28925/2312-5829.2021.39

УДК 378.046-021.68

\title{
ВІКТОРІЯ НАУМОВА
}

Київський університет імені Бориса Грінченка,

м.Київ, Україна

v.naumova@kubg.edu.ua, ORCID iD 0000-0002-0114-4749

\section{ОСОБЛИВОСТІ ПРОФЕСІЙНОЇ СПРЯМОВАНОСТІ ПЕДАГОГІЧНИХ ПРАЦІВНИКІВ В УМОВАХ ПІСЛЯДИПЛОМНОЇ ОСВІТИ}

Стаття присвячена експериментальній перевіриі особистісних особливостей професійної спрямованості педагогічних працівників в умовах післядипломноі освіти.

У ході теоретичного аналізу психолого-педагогічної літератури встановлено, щцо розвиток професійної спрямованості педагогічних працівників в умовах післядипломної освіти відбувається в тісному взаємозв'язку з професійним й особистісним розвитком самої особистості педагога. Завданнями емпіричного дослідження було: здійснити відбір психодіагностичних методик $i$ тестів, які дозволять виокремити особливості професійної спрямованості педагогічних працівників; сформувати репрезентативну вибірку педагогічних працівників; провести діагностування респондентів, здійснити математичну обробку отриманих даних; описати взаємозв'язок особливостей, які впливають на професійну спрямованість у педагогічних прачівників та інтерпретувати результати. Дослідно-експериментальна робота передбачала використання виключно адаптованих $i$ стандартизованих методик $i$ тестів. Це сприяло отриманню надійних та валідних результатів, які характеризують особливості професійної спрямованості педагогічних працівників. Доведено й експериментально підтверджено, що до основних особистісних особливостей професійної спрямованості педагогічних працівників в умовах післядипломної освіти слід віднести внутрішню мотивачію, рівень емпатії, рівень самооиінки, рівень соціального самоконтролю. З'ясовано, що у професійній спрямованості педагогічних прачівників слід виокремити мотиваційну, емпатичну та оцінювальну складові. Отримані результати емпіричного дослідження свідчать про дочільність організації спеціальної психолого-педагогічної роботи зі слухачами курсів підвищення кваліфікації в умовах післядипломної педагогічної освіти, спрямованої на розвиток професійної спрямованості педагогічних працівників. У перспективі необхідно приділити увагу вивченню організаційно-педагогічних $i$ психологопедагогічних умов взаємозалежності педагогічної спрямованості та професійного розвитку педагогічного прачівника.

Ключові слова: педагогічні прачівники, післядипломна освіта, професійний розвиток, професійна спрямованість. 
Вступ. Суперечності між викликами сьогодення та традиційною системою післядипломної освіти вимагають пошуку нових підходів у підвищені кваліфікації педагогічних працівників. Суспільство вимагає педагогів нового типу: 3 високим професіоналізмом, стійкою професійною спрямованістю, 3 готовністю до впровадження освітніх інновацій. Серед перспективних завдань післядипломної педагогічної освіти називаються оновлення цілей i змісту освіти на основі компетентнісного підходу й особистісної орієнтації.

На особливу увагу заслуговує думка О. Волярської (Волярська, 2020, с.37) про те, що «країни, які прагнуть сформувати розвинене суспільство й конкурентоспроможну економіку, як ніколи стурбовані необхідністю постійного оновлення знань у працездатного населення, підвищенням кваліфікації співробітників, розширенням можливостей для їхнього професійного розвитку у форматі формальної і неформальної вищої освіти». Отже, роль післядипломної освіти у сучасному суспільстві постійно зростає.

Подібна специфіка неперервності у професійному розвитку педагогів висвітлена у праці українських науковців Г. Філіпчука, М. Вовк, К. Котуна, Л. Ходацької, які стверджують, що «неперервний розвиток сучасного педагога, формування його як людини культури, агента змін, інноваційної особистості передбачає створення ефективних умов для професійного зростання, особистісного саморозвитку через використання потенційних можливостей сучасного інформаційного суспільства» (Philipchuk, Vovk, Kotun \& Khodatska, 2020, с. 15).

Можливості використання потенціалу післядипломної освіти у підготовці конкурентоздатних фахівців висвітлено у праці Т. Стойчик (2020). Авторка стверджує, що формування конкурентоздатності фахівця потребує створення відповідних педагогічних умов для особистісно-професійного становлення суб'єкта праці.

В. Огнев’юк і С. Сисоєва стверджують, що взаємодія із зовнішнім середовищем $\epsilon$ фактором внутрішньої самоорганізації як цілої системи освіти, так і окремої особистості, впливає на розвиток системи цінностей (Огнев’юк та Сисоєва, 2013). 
Г. Кашина (2018), досліджуючи теоретико-методичні засади інформаційнотехнологічного забезпечення підготовки педагогів у системі післядипломній освіти, відмічає, що врахування особистісних якостей слухачів впливає на формування їхніх життєвих орієнтирів, власних траєкторій самореалізації педагогів, на розвиток креативного потенціалу педагогів.

Як зазначає С. Мірошник (2016), компетентнісний підхід акцентує увагу на результатах освітньої діяльності, отже, результат освіти слід розглядати не як суму засвоєної інформації, а як здатність особистості діяти в різних життєвих і професійних ситуаціях; він передбачає оцінку готовності фахівців певного освітньокваліфікаційного рівня до професійної діяльності на основі наявності в них визначених стандартами компетентностей. У контексті нашого дослідження саме компетентнісний підхід визначає необхідність розгляду формування й особливостей розвитку професійної спрямованості педагогічних працівників в умовах післядипломної освіти.

Дослідженню проблеми професійної спрямованості присвячені наукові праці зарубіжних й українських психологів і педагогів. Різні аспекти професійної спрямованості вивчали Н. Кузьміна, О. Леонтьєв, Л. Мітіна, С. Рубінштейн. Рівні сформованості професійної спрямованості були предметом вивчення В. Сластьоніна. Методам діагностики структурних компонентів професійної спрямованості присвячено праці С. Ільїна, А. Реана.

Педагогічна спрямованість особистості як базова основа розвитку професійної позиції майбутнього вчителя $\epsilon$ предметом дослідження О. Літовки (2014). Дослідниця встановила, що «професійна спрямованість особистості є визначальним чинником при виборі майбутньої професії та позиції в цій професії, а також, характеристикою якості виконання професійної діяльності фахівцями різного профілю» (Літовка, 2014, с. 221).

Професійна спрямованість $є$ результатом формування системи ціннісних мотивів, які спонукають особистість до засвоєння професійних знань, умінь, навичок і способів їх творчого використання на практиці. Професійна спрямованість містить у собі предметний зміст і світогляд особистості (Літовка, 2014, с. 220). 
C. Day (2018) ключовими складовими професійної ідентичності, професіоналізму вчителя вважає свободу, емоційне благополуччя, психологічну стійкість. J. Nickel, J. Zimmer (2018) серед вимірів професійної ідентичності вчителя акцентували професійне цілепокладання і прихильність до викладацької професії.

Аналіз наукових праць дозволяє стверджувати, що розвиток професійної спрямованості педагогічних працівників в умовах післядипломної освіти відбувається в тісному взаємозв'язку з професійним й особистісним розвитком самої особистості педагога. Саме професійна спрямованість припускає наявність у педагогічних працівників мотивів до педагогічної діяльності, усвідомлення способів самопізнання, самоконтролю, самоактуалізації, має прояв у позитивному ставленні до професії. Так, S. Y. F. Tang et al. (2015) досліджували мотивацію 132 учителів під час їхнього навчання за післядипломною освітньою програмою і виявили позитивну кореляцію між внутрішньо-альтруїстичною мотивацією та окремими гранями професійної компетентності.

Суспільна значимість та об'єктивна потреба держави в ефективному професійному розвитку педагогічних працівників у післядипломній освіті, а також недостатня вивченість проблеми професійної спрямованості педагогів зумовили вибір теми нашого дослідження.

Мета статті полягає в експериментальній перевірці особистісних особливостей професійної спрямованості педагогічних працівників в умовах післядипломної освіти.

Основними завданнями дослідження було: 1) здійснити відбір психодіагностичних методик i тестів, які дозволять виокремити особливості професійної спрямованості педагогічних працівників; 2) сформувати репрезентативну вибірку педагогічних працівників; 3) провести діагностування респондентів, здійснити математичну обробку отриманих даних; 4) описати взаємозв'язок особливостей, які впливають на професійну спрямованість у педагогічних працівників та інтерпретувати результати.

Методологія. Методи дослідження: 1) емпіричні: опитування; методика «Мотиви вибору професії» в редакції Р. Овчарова; тест «Визначення рівня 
самооцінки» С. Ковальова; методика І. Юсупова «Діагностика рівня емпатії»; методика «Шкала соціального самоконтролю» М. Снайдера в адаптації Н. Амяга; 2) методи математичної статистики: описова статистика, кореляційний аналіз (коефіцієнт парної кореляції Пірсона).

Наголосимо, що дослідно-експериментальна робота передбачала використання виключно адаптованих і стандартизованих методик і тестів, це сприяло отриманню надійних та валідних результатів, які характеризують особливості професійної спрямованості педагогічних працівників. Опрацювання результатів здійснено за допомогою компьютерного пакету статистичних програм Excel.

Базуючись на результатах теоретичного опрацювання наукових джерел 3 проблеми дослідження, ми визначили завдання та запропонували гіпотезу дослідження, яка полягає в припущенні, що до основних особистісних особливостей професійної спрямованості педагогічних працівників в умовах післядипломної освіти слід віднести такі: внутрішню мотивацію, рівень емпатії, рівень самооцінки, рівень соціального самоконтролю.

Результати дослідження. Для проведення емпіричного дослідження нами було сформовано вибірку досліджуваних у кількості 40 педагогічних працівників: слухачів курсів підвищення кваліфікації Інституту післядипломної освіти Київського університету імені Бориса Грінченка. Дані, що отримані у ході діагностування досліджуваних, піддавалися опису, наочному представленню та кореляційному аналізу.

У результаті опитування нами визначено розподіл респондентів за статтю і стажем педагогічної діяльності. Так, за статтю розподіл такий: 26 осіб (65,0\%) - це жінки, $14(35,0 \%)$ - чоловіки. Розподіл респондентів за стажем педагогічної діяльності: 9 осіб (22,5\%) мають педагогічних досвід роботи від 5 до 10 років; 7 осіб (17,5\%) - від 11 до 15 років; 4 (10,0 \%) - від 16 до 20 років; 20 (50,0\%) педагогічних працівників працюють в освіті більше 20 років. Більшість педагогічних працівників мають стаж роботи в освітній галузі понад 10 років.

Проаналізуємо результати діагностування за методикою «Мотиви вибору професії» в редакції Р. Овчарова (див. Рис. 1). Встановлено, що в педагогічних 
працівників превалюють внутрішні індивідуально значущі мотиви (визначило 20 (50,0\%) досліджуваних) і зовнішні позитивні мотиви (13 (32,5\%) досліджуваних). Внутрішні соціально значущі мотиви визначили 5 (12,5\%) досліджуваних. Зовнішні негативні мотиви визначили лише 2 педагога (5,0\% досліджуваних).

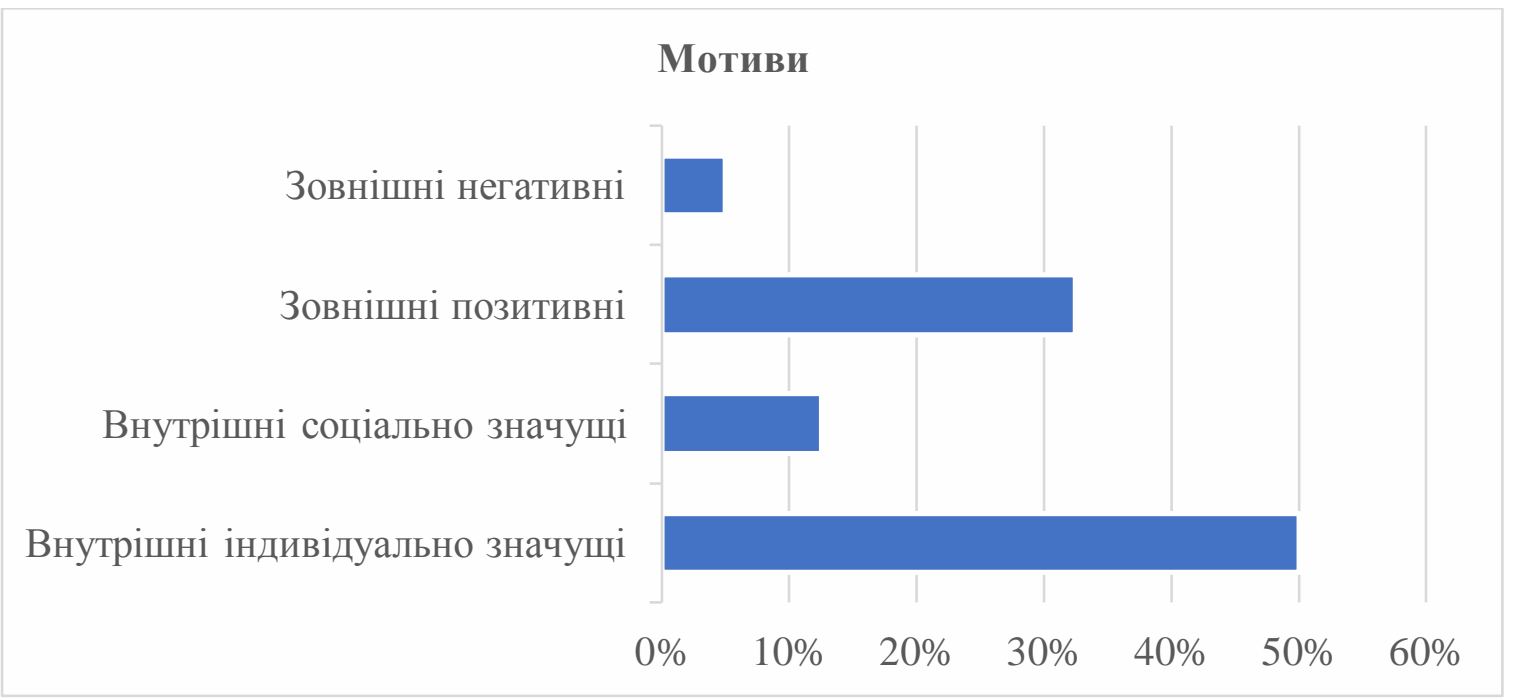

\section{Рисунок 1. Мотиви вибору професії педагогічними працівниками}

Вважаємо, що внутрішні індивідуальні мотиви характеризують професійну спрямованість педагогічних працівників. Саме усвідомлення ближніх (безпосередніх) і кінцевих (перспективних) цілей професійної діяльності, прагнення до усвідомлення теоретичної і практичної значущості власної педагогічної професії, готовність до впровадження освітніх інновацій мають для досліджуваних особистісний зміст.

Проаналізуємо результати діагностування педагогічних працівників за тестом «Визначення рівня самооцінки» С. Ковальова. Отримані у ході діагностування дані узагальнено в Табл. 1.

Визначення рівня самооцінки педагогічних працівників

\begin{tabular}{|c|c|c|}
\hline Рівні самооцінки & К-ть & $\%$ \\
\hline Низький & 4 & 10,0 \\
\hline Середній & 13 & 32,5 \\
\hline Високий & 23 & 57,5 \\
\hline Разом & 40 & 100 \\
\hline
\end{tabular}


Результати діагностування показали, що в 57,5\% педагогічних працівників встановлений високий рівень самооцінки. 3 них в 5 (12,5\%) досліджуваних було визначено від 0 до 4 балів, що свідчить про повну адекватність усвідомлення себе, наданням власним діям і вчинкам чітких оцінок. У 18 (45\%) досліджуваних були встановлені бали від 5 до 25 , що також характеризує високий рівень їхньої особистісної самооцінки. Ці педагоги адекватно реагують на зауваження оточуючих і можуть надати оцінку власній поведінці.

3 даних, наведених у Табл. 1, видно, що середній рівень самооцінки було встановлено у 13 (32,5\%) досліджуваних. Такі педагогічні працівники час від часу відчувають, але не можуть усвідомити причину відсутності розуміння 3 оточуючими, вони нерідко недооцінюють себе, не вірять у власні здібності. Низький рівень самооцінки було визначено у 4 (10\%) досліджуваних. Педагоги з низькою самооцінкою болісно реагують на критичні зауваження в свій бік, бажають враховувати судження інших людей, а не власні.

Вважаємо, що адекватна самооцінка педагогічних працівників позитивно впливає на віру вчителя у свою здатність організовувати та виконувати курс дій, необхідних для успішного виконання конкретного завдання в професійному контексті. L. Gaikhorst et al. (2017), використовуючи на позначення такої професійної віри у свої сили термін «самоефективність», стверджують, що програми професійного розвитку повинні сприяти підвищенню самоефективності вчителів, оскільки викладачі з високою самоефективністю менше зазнають професійного вигорання і менше схильні до ризику залишити педагогічну професію.

Узагальнення результатів дослідження педагогічних працівників за методикою I. Юсупова «Діагностика рівня емпатії» дозволило констатувати, що в 46,25\% досліджуваних встановлено середній рівень емпатії, у 31,25\% - високий, у 20\% визначено низький рівень та в 2,5\% - дуже високий. Відзначимо відсутність у досліджуваних низького рівня емпатії.

Узагальнені результати діагностування педагогічних працівників за методикою «Шкала соціального самоконтролю» М. Снайдера в адаптації Н. Амяга зображено на Рис. 2. 


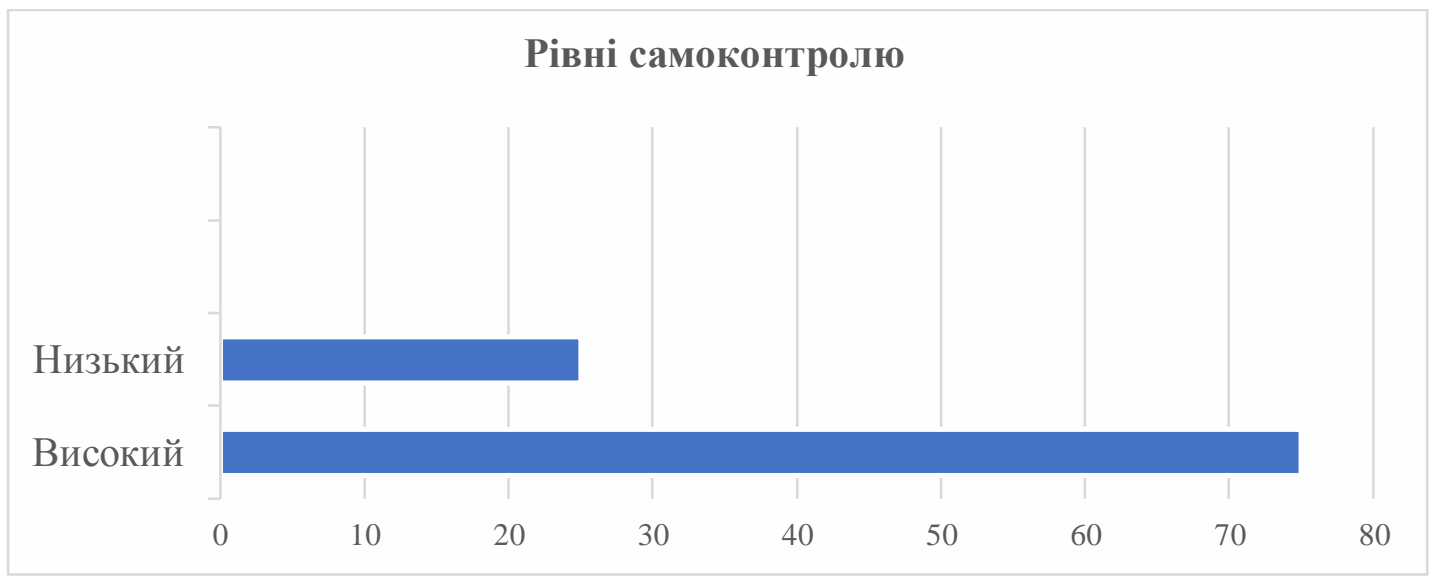

\section{Рисунок 2. Результати діагностування педагогічних працівників за методикою «Шкала соціального самоконтролю» М. Снайдера в адаптації Н. Амяга}

Як свідчить інфографіка, у 30 (75,0\%) педагогів встановлено високий рівень самоконтролю. Цей рівень характеризується тим, що він відрізняється активністю та самостійністю контролювання дій особистості, здібностей, вчинків у професійних ситуаціях. Для цього рівня розвитку самоконтролю педагогічних працівників характерно: самостійне визначення мети професійної діяльності та способів іiі досягнення, усвідомлення та самостійне оцінювання виконаної роботи, власної поведінки, виявлення помилок в освітній діяльності, розуміння їх причин, самостійне корегування власної педагогічної діяльності. У 10 (25,0\%) педагогічних працівників визначено низький рівень самоконтролю. Цей рівень характеризується частковим проявом активності і самостійності при контролі власних дій, здібностей, поведінки тощо. Загалом, як засвідчило дослідження, в опитаних педагогічних працівників показники високого рівня соціального контролю значно перевищують показники низького рівня.

За результатами емпіричного дослідження можна стверджувати, що в професійній спрямованості педагогічних працівників слід виокремити мотиваційну, емпатичну та оцінювальну складові. Так, до мотиваційної складової слід віднести внутрішні індивідуально значущі мотиви, внутрішні соціально значущі мотиви і зовнішні позитивні мотиви особистості. Найбільший показник щодо мотивів вибору педагогів встановлено для внутрішніх індивідуально значущих мотивів (ці мотиви визначило 20 (50,0\%) досліджуваних). Підкреслимо, що 2 педагога $(5,0 \%$ досліджуваних) визначило зовнішні негативні мотиви як мотиви вибору. Це, на 
нашу думку, є негативним аспектом, який впливає на професійну спрямованість визначених педагогічних працівників.

До емпатичної складової професійній спрямованості педагогічних працівників у контексті нашого дослідження слід віднести встановлений у педагогів рівень емпатії. За отриманими в ході діагностування даними було обчислено середнє значення емпатії досліджуваних педагогів $\overline{\mathrm{X}}=53,18$ бали. Такий показник свідчить про те, що для більшості педагогів емпатія знаходиться на середньому рівні.

До оцінювальної складової слід віднести рівень самооцінки i рівень самоконтролю педагогічних працівників. За отриманими у ході діагностування даними обчислено середнє значення самооцінки досліджуваних педагогів $\overline{\mathrm{X}}=37,55$ бали. Такий показник свідчить про те, що для загальної кількості досліджуваних самооцінка визначена на середньому рівні. Отже, для педагогічних працівників характерними є неможливість усвідомлювати причини відсутності розуміння 3 оточуючими, недооцінка власних здібностей.

Привертають увагу наявність відмінності в рівнях самооцінки та емпатії педагогічних працівників та їхня однорідність у рівнях самоконтролю. У зв’язку 3 цим, а також 3 метою емпіричного підтвердження виокремлених у ході аналізу особливостей професійної спрямованості педагогічних працівників проведемо кореляційний аналіз. Дослідимо залежність показників самооцінки та емпатії.

За даними визначення парної кореляції Пірсона між показниками самооцінки та емпатії встановлено, що між рівнем самооцінки і рівнем емпатії педагогічних працівників існує слабка пряма залежність: $\mathrm{r}=0,14$. Отже, в досліджуваних самооцінка слабо впливає на їхню емпатію. Акцентуємо увагу на тому, що в процесі проведення педагогічної взаємодії із педагогічними працівниками на курсах підвищення кваліфікації слід враховувати таку особистісну особливість як слабкий вплив самооцінки на прояви емпатії.

Результати проведеного емпіричного дослідження дозволили відзначити правомірність висунутої гіпотези. Доведено й експериментально підтверджено, що до основних особистісних особливостей професійної спрямованості педагогічних працівників в умовах післядипломної освіти слід віднести внутрішню мотивацію, 
рівень емпатії, рівень самооцінки, рівень соціального самоконтролю. Наголосимо, що отримані результати емпіричного дослідження свідчать про доцільність організації спеціальної психолого-педагогічної роботи зі слухачами курсів підвищення кваліфікації в умовах післядипломної педагогічної освіти, спрямованої на розвиток професійної спрямованості педагогічних працівників.

Післядипломна педагогічна освіта, іiі якість та рівень формують професійну спрямованість педагогічних працівників, забезпечуючи їх професійний розвиток i професіоналізм. Зважаючи на український та закордонний досвід, з метою розвитку професійної спрямованості педагогів пропонуємо використання в процесі підвищення кваліфікації в системі післядипломної освіти проблемно-ситуативного моделювання, а також урахування їхніх особистісних характеристик.

Висновки. Таким чином, у результаті нашого дослідження доведено, що професійна спрямованість особистості педагогічного працівника, яка грунтується на позитивній професійній мотивації, рівні самооцінки і рівні самоконтролю, ставленні до педагогічної професії, виступає вагомою підставою для визначення напрямів удосконалення професіоналізму.

Перспективи подальших досліджень в обраному напрямі ми пов'язуємо 3 вивченням організаційно-педагогічних і психолого-педагогічних умов взаємозалежності педагогічної спрямованості та професійного розвитку педагогічного працівника.

\section{Література}

Волярська О. С. Напрями розвитку вищої освіти в Україні в умовах нестабільності. Освіта дорослих: теорія, досвід, перспективи: збірник наук. пращь. 2020. Вип. 2 (18). C. 34-43. DOI: $10.35387 /$ od.2(18).2020. C. 34-43

Кашина Г. С. Науково-природнича підготовка педагогів у системі післядипломної освіти засобами інформаційно-технологічного забезпечення: монографія. Херсон : Вид-во «ОЛДІ-ПЛЮС», 2018. 315 с.

Літовка О. П. Педагогічна спрямованість особистості як базова основа розвитку професійної позиції майбутнього вчителя. Педагогіка формування творчої особистості у вищій $і$ загальноосвітній школах. 2014. Вип. 38. С. 216-219.

Освітологія: хрестоматія: навчальний посібник для студентів вищих навчальних закладів. Укладачі : В. О. Огнев’юк, С. О. Сисоєва. Київ: Едельвейс, 2013. 744 c. 
Мірошник С. I. Професійний розвиток педагога: сучасні підходи. Народна освіта. 2016. Випуск № 2 (29). URL: www.narodnaosvita.kiev.ua/ (дата звернення: 08.07.2021).

Стойчик T. I. Концептуальні основи управління якістю підготовки конкурентоздатних фахівців. Вісник післядипломної освіти. Серія «Педагогічні науки». 2020. Вип. 13 (42). С. 240-258. DOI: 10.32405/2218-7650-2020-13(42)240-258

Day C. Professional Identity Matters: Agency, Emotions, and Resilience. Schutz P., Hong J., Cross Francis D. (Eds.). Research on Teacher Identity. Cham: Springer, 2018. C. 61-70. DOI: 10.1007/978-3-319-93836-3_6

Gaikhorst L., Beishuizen J. J. J., Zijlstra B. J. H. \& Volman M. L. L. The sustainability of a teacher professional development programme for beginning urban teachers. Cambridge Journal of Education. 2017. № 47 (1). C. 135-154. DOI: https://doi.org/10.1080/0305764X.2015.1125449

Nickel J. \& Zimmer J. Professional identity in graduating teacher candidates. Teaching

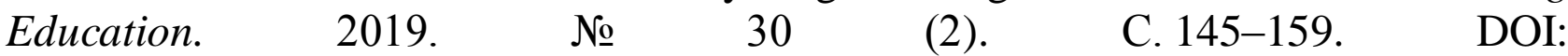
https://doi.org/10.1080/10476210.2018.1454898

Philipchuk H. H., Vovk M. P., Kotun K. V., \& Khodatska O. M. Ukrainian Electronic Resources Potential for Pedagogical Education: Experience of Ukraine and Canada. Information Technologies and Learning Tools. 2020. № 78 (4). C. 14-31. DOI: https://doi.org/10.33407/itlt.v78i4.3612

Tang S. Y. F., Wong A. K. Y. \& Cheng M. M. H. The preparation of highly motivated and professionally competent teachers in initial teacher education. Journal of Education for Teaching. 2015. № 41 (2). 128-144. DOI: 10.1080/02607476.2015.1010875

\section{References}

Voliarska, O. S. (2020). Napriamy rozvytku vyshchoi osvity v Ukraini v umovakh nestabilnosti [Directions of higher education development in ukraine in conditions of instability]. Osvita doroslykh: teoriia, dosvid, perspektyvy, 2 (18), 34-43. DOI: 10.35387/od.2(18).2020. 34-43 (in Ukrainian).

Kashyna, H. S. (2018). Naukovo-pryrodnycha pidhotovka pedahohiv u systemi pisliadyplomnoi osvity zasobamy informatsiino-tekhnolohichnoho zabezpechennia: monohrafiia [Scientific and natural training of teachers in the system of postgraduate education by means of information and technological support: monograph]. OLDIPLIuS (in Ukrainian).

Litovka, O. P. (2014). Pedahohichna spriamovanist osobystosti yak bazova osnova rozvytku profesiinoi pozytsii maibutnoho vchytelia [Pedagogical orientation of the individual as the basic foundation of the future teacher professional position]. Pedahohika formuvannia tvorchoi osobystosti u vyshchii i zahalnoosvitnii shkolakh, 38, 216-219 (in Ukrainian).

Ohneviuk, V. O. \& Sysoieva, S. O. (Eds.) (2013). Osvitolohiia: khrestomatiia: navchalnii posibnik dlia studentiv vyshchykh navchalnykh zakladiv [Osvitology: a textbook for students of higher educational institutions]. Edelveis (in Ukrainian). 
Miroshnyk, S. I. (2016). Profesiinyi rozvytok pedahoha: suchasni pidkhody [Professional Development of Teachers: Modern Approaches]. Narodna osvita, 2 (29). www.narodnaosvita.kiev.ua/. (in Ukrainian).

Stoichyk, T. I. (2020). Kontseptualni osnovy upravlinnia yakistiu pidhotovky konkurentozdatnykh fakhivtsiv [Conceptual basics of quality management for training of competitive specialists]. Visnyk pisliadyplomnoi osvity. Seriia «Pedahohichni nauky», 13 (42), 240-258. DOI: 10.32405/2218-7650-2020-13(42)240-258 (in Ukrainian).

Day, C. (2018). Professional Identity Matters: Agency, Emotions, and Resilience. In P. Schutz, J. Hong, D. Cross Francis (Eds.), Research on Teacher Identity (pp. 61-70). Springer. DOI: 10.1007/978-3-319-93836-3_6 (in English).

Gaikhorst, L., Beishuizen, J. J. J., Zijlstra, B. J. H. \& Volman, M. L. L. (2017). The sustainability of a teacher professional development programme for beginning urban teachers. Cambridge Journal of Education, 47 (1), 135-154. DOI: 10.1080/0305764X.2015.1125449 (in English).

Nickel, J. \& Zimmer J. (2019). Professional identity in graduating teacher candidates. Teaching Education, 30 https://doi.org/10.1080/10476210.2018.1454898

Philipchuk, H. H., Vovk, M. P., Kotun, K. V., \& Khodatska, O. M. (2020). Ukrainian Elektronic Resources Potential for Pedagogical Education: Experience of Ukraine and Canada. Information Technologies and Learning Tools, 78 (4), 14-31. DOI: 10.33407/itlt.v78i4.3612 (in English).

Tang, S. Y. F., Wong, A. K. Y. \& Cheng, M. M. H. (2015). The preparation of highly motivated and professionally competent teachers in initial teacher education. Journal of Education for Teaching, 41 (2), 128-144. DOI: 10.1080/02607476.2015.1010875 (in English).

\section{ВИКТОРИЯ НАУМОВА,}

Киевский университет имени Бориса Гринченко,

г. Киев, Украина

v.naumova@kubg.edu.ua, ORCID iD 0000-0002-0114-4749

\section{ОСОБЕННОСТИ ПРОФЕССИОНАЛЬНОЙ НАПРАВЛЕННОСТИ ПЕДАГОГИЧЕСКИХ РАБОТНИКА В УСЛОВИЯХ ПОСЛЕДИПЛОМНОГО ОБРАЗОВАНИЯ}

Статья посвящена экспериментальной проверке личностных особенностей профессиональной направленности педагогов в условиях последипломного образования.

В ходе теоретического анализа психолого-педагогической литературы установлено, что развитие профессиональной направленности педагогов в условиях последипломного образования происходит в тесной взаимосвязи с профессиональным и личностным развитием самой личности педагога. Задачами эмпирического исследования были: осуществить отбор психодиагностических 
методик и тестов, которые позволят выделить особенности профессиональной направленности педагогических работников; сформировать репрезентативную выборку педагогических работников; провести диагностирование респондентов, осуществить математическую обработку полученных данных; описать взаимосвязь особенностей, которые влияют на профессиональную направленность педагогических работников, и интерпретировать результатьл. Экспериментальная работа предусматривала использование исключительно адаптированных $u$ стандартизированных методик и тестов, это способствовало получению надежных и валидных результатов, характеризующих особенности профессиональной направленности педагогических работников. Доказано и экспериментально подтверждено, что к основным личностным особенностям профессиональной направленности педагогов в условиях последипломного образования следует отнести внутреннюю мотивацию, уровень эмпатии, уровень самооценки, уровень сочииального самоконтроля. Установлено, что в профессиональной направленности педагогов следует выделить мотивационную, эмпатическое и оченочную составляющчие. Полученные результаты эмпирического исследования свидетельствуют о цеелесообразности организации спецчиальной психолого-педагогической работы со слушателями курсов повышения квалификации в условиях последипломного педагогического образования, направленной на развитие профессиональной направленности педагогических работников. $B$ перспективе необходимо уделить внимание изучению организационно-педагогических $и$ психолого-педагогических условий взаимозависимости педагогической направленности и профессионального развития педагога.

Ключевые слова: педагогические работники, последипломное образование, профессиональная направленность, профессиональное развитие.

\section{VIKTORIIA NAUMOVA,}

Borys Grinchenko Kyiv University, Kyiv, Ukraine

v.naumova@kubg.edu.ua, ORCID iD 0000-0002-0114-4749

\section{PECULIARITIES OF PROFESSIONAL ORIENTATION OF PEDAGOGUES IN THE CONDITIONS OF POSTGRADUATE EDUCATION}

The article is devoted to the experimental verification of personal features of professional orientation of pedagogues in the conditions of postgraduate education.

In the course of theoretical analysis of psychological and pedagogical literature it is established that the development of professional orientation of teachers in postgraduate education is closely related to the professional and personal development of the teacher. The objectives of the empirical study were: to select psychodiagnostic techniques and tests that will highlight the features of the professional orientation of teachers; to form a representative sample of teachers; to diagnose respondents, to carry out mathematical processing of the received data; describe the relationship of features that affect the professional orientation of teachers and interpret the results. Experimental work involved the using of exclusively adapted and standardized methods and tests, it contributed to 
obtaining reliable and valid results that characterize the features of the professional orientation of teachers. It is proved and experimentally confirmed that the main personal features of professional orientation of teachers in postgraduate education should include intrinsic motivation, level of empathy, level of self-esteem, level of social self-control. It was found that the motivational, empathic and evaluative components should be distinguished in the professional orientation of pedagogues. The obtained results of the empirical research testify to the expediency of organizing special psychological and pedagogical work with students of advanced training courses in the conditions of postgraduate pedagogical education, aimed at the development of professional orientation of pedagogues. In the future it is necessary to pay attention to the study of organizationalpedagogical and psychological-pedagogical conditions of interdependence of pedagogical orientation and professional development of a pedagogue.

Key words: pedagogues, professional orientation, professional development, postgraduate education.

Стаття надійшла до редакції 13.07.2021

Прийнято до друку 23.09 2021 